\title{
PENGARUH DISIPLIN KERJA, KOMITMEN ORGANISASI DAN KEMAMPUAN KERJA TERHADAP KINERJA PEGAWAI DINAS SOSIAL DAERAH KABUPATEN TAPANULI SELATAN
}

\author{
${ }^{1}$ Nelli Molida Harahap, ${ }^{2}$ Budi Krianto S., ${ }^{3}$ Veronika Dumaria S, ${ }^{4}$ Asikin Kesuma, ${ }^{5}$ Surya Gunawan \\ $1,2,3,4,5$ Universitas Islam Sumatera Utara \\ ${ }^{1}$ nelli.molida@gmail.com, ${ }^{2}$ budi.krianto@gmail.com, ${ }^{3}$ veronica.dumaria@gmail.com, ${ }^{4}$ asikin.kesuma@gmail.com, \\ ${ }^{5}$ surya.gunawan@gmail.com
}

\begin{abstract}
The formulation in this research is how the influence of work discipline, organizational commitment and work ability to the performance of social service officers in the district of South Tapanuli, and the purpose of this research is to know and analyze The influence of work discipline, organizational commitment and work ability to the performance of social service employees of the District of South Tapanuli. This research is quantitative descriptive research. Data collection techniques are conducted through interviews, inquiry lists and documentation studies. The samples in this study were as many as 32 employees. Variables are measured at Likert scale. Hypothesis testing using multiple linear regression analyses through F-test and T-Test. results of the test in Unison indicate that the work discipline, organizational commitment and work ability have significant effect on the performance of officers in the social service office in the District of South Tapanuli regency with a value of $F_{\text {count }} 15,929>F_{\text {table }} 2.90$ and significance value of $0.000^{b}$. The Adjusted number of $R$ Square is 0.591 or (59.1\%) Indicates that the percentage of contributions influenced by independent variables (work discipline, organizational commitment and work ability) on dependent variables (employee performance) of $59.1 \%$. Partially, the work discipline significantly affects the performance of officers in the social service office of the District of South Tapanuli regency with a value of $t_{\text {count }}>t_{\text {table }}(3,990>2,037)$ and a significance value of 0.000 . The organizational commitment has a significant effect on the performance of employees at the social Service office of South Tapanuli regency with a value of $t_{\text {count }}>t_{\text {table }}(2,717>2,037)$ and significance value of 0. 011. Work capability significantly affects the employee 's performance in the social service office of the South Tapanuli district with a value of $t_{\text {count }}>t_{\text {table }}(3,135>2,037)$ and a significance value of 0.004 . The Highest value of a regression coefficient is a working discipline variable $\left(X_{1}\right)$ of 0.494 or $43.0 \%$ and is the most dominant variable affecting employee performance in the social service office of South Tapanuli District
\end{abstract}

Keywords: work discipline, organizational commitment, self-ability, performance

ABSTRAK : Rumusan pada penelitian ini adalah bagaimana pengaruh disiplin kerja, komitmen organisasi dan kemampuan kerja terhadap kinerja pegawai Dinas Sosial Daerah Kabupaten Tapanuli Selatan, dan tujuan penelitian ini adalah untuk mengetahui dan menganalisis pengaruh disiplin kerja, komitmen organisasi dan kemampuan kerja terhadap kinerja pegawai Dinas Sosial Daerah Kabupaten Tapanuli Selatan. Penelitian ini merupakan penelitian deskriptif kuantitatif. Teknik pengumpulan data dilakukan melalui wawancara, daftar pertanyaan dan studi dokumentasi. Sampel dalam penelitian ini sebanyak 32 orang pegawai. Variabel diukur dengan skala Likert. Pengujian hipotesis menggunakan analisis regresi linear berganda melalui uji $F$ dan uji t. Hasil uji secara serempak menunjukkan bahwa disiplin kerja, komitmen organisasi serta kemampuan kerja berpengaruh signifikan terhadap kinerja pegawai di Kantor Dinas Sosial Daerah Kabupaten Tapanuli Selatan dengan nilai $F_{\text {hitung }} 15.929>F_{\text {tabel }} 2.90$ dan nilai signifikansi sebesar $0.000^{b}$. Angka Adjusted $R$ Square sebesar 0.591 atau (59.1\%) menunjukkan bahwa persentase sumbangan pengaruh variabel independen (disiplin kerja, komitmen organisasi serta kemampuan kerja) terhadap variabel dependen (kinerja pegawai) sebesar 59.1\%. Secara parsial, disiplin kerja berpengaruh signifikan terhadap kinerja pegawai di Kantor Dinas Sosial Daerah 
Kabupaten Tapanuli Selatan dengan nilai $t_{\text {hitung }}>t_{\text {tabel }}(3.990>2.037)$ dan nilai signifikansi sebesar 0.000. Komitmen organisasi berpengaruh signifikan terhadap kinerja pegawai di Kantor Dinas Sosial Daerah Kabupaten Tapanuli Selatan dengan nilai $t_{\text {hitung }}>t_{\text {tabel }}(2.717>2.037)$ dan nilai signifikansi sebesar 0.011. Kemampuan kerja berpengaruh signifikan terhadap kinerja pegawai di Kantor Dinas Sosial Daerah Kabupaten Tapanuli Selatan dengan nilai $t_{\text {hitung }}>t_{\text {tabel }}$ (3.135 > 2.037) dan nilai signifikansi sebesar 0.004. Nilai koefisien regresi yang paling tinggi adalah variabel disiplin kerja $\left(X_{1}\right)$ sebesar 0.494 atau $43.0 \%$ dan merupakan variabel yang paling dominan mempengaruhi kinerja pegawai di Kantor Dinas Sosial Daerah Kabupaten Tapanuli Selatan

\section{Kata kunci : Disiplin Kerja, Komitmen Organisasi, Kemampuan Diri, Kinerja}

\section{Pendahuluan}

Dinas Sosial Daerah Kabupaten Tapanuli Selatan dalam melaksanakan setiap program yang tertuang dalam program kerja diharapkan dapat menerapkan prinsip-prinsip transparansi, efisien dan akuntabilitas. Prinsip ini diperlukan sebagai semangat guna mendukung program pelaksanaan pengelolaan pemerintah yang baik (good governance). Dinas Sosial Daerah Kabupaten Tapanuli Selatan dalam melaksanakan tugas sesuai dengan struktur organisasi yang memungkinkan sumber daya manusia yang berkualitas dan kompetitif sehingga mampu beradaptasi dengan kemajuan dan perkembangan ilmu dan teknologi guna menghasilkan kinerja dan pelayanan terbaik sesuai dengan yang diharapkan.

Menurut pendapat Colquitt (2009:273), kinerja adalah nilai dari seperangkat perilaku pegawai yang berkontribusi secara positif dan negatif untuk mencapai tujuan organisasi. Kinerja memiliki 3 (tiga) dimensi yaitu perilaku tugas, perilaku moral dan perilaku menantang. Perilaku tugas adalah tingkah laku pegawai yang terlibat secara langsung dalam mentransformasikan sumber organisasi dalam kebajikan, pelayanan atau produksi organisasi. Perilaku tugas meliputi tugas rutin dan tugas dalam pembaharuan. Perilaku moral adalah aktivitas dalam bentuk kesukarelaan dari pegawai ada reward atau tidak ada reward akan tetapi tetap memberikan kontribusi pada organisasi guna memperbaiki kualitas secara keseluruhan di tempat kerja.

Penelitian tentang kinerja pegawai telah banyak dilakukan oleh para peneliti sebelumnya, dan berdasarkan survei awal, faktor yang mempengaruhi kinerja pegawai Dinas Sosial Daerah Kabupaten Tapanuli Selatan adalah komitmen organisasi. Sekarang ini komitmen organisasi dapat dijadikan landasan daya saing, karena organisasi atau instansi dengan pegawai yang mempunyai komitmen akan mendapatkan keunggulankeunggulan yang tidak dimiliki oleh organisasi atau instansi lain seperti adanya kepercayaan yang kuat untuk menerima tujuan dan nilai-nilai organisasi, kesediaan untuk melakukan usaha yang diatasnamakan organisasi, serta adanya keinginan yang kuat untuk mempertahankan keanggotaannya di dalam organisasi tersebut.

Colquitt (2009:77) berpendapat bahwa komitmen organisasi didefinisikan sebagai hasrat yang dimiliki oleh seorang pegawai untuk tetap menjadi anggota suatu organisasi atau komitmen organisasi akan mempengaruhi sikap atau perilaku pegawai untuk tetap bekerja di suatu organisasi atau meninggalkan organisasi. Sri Yani (2005), menjelaskan bahwa kompetensi manajerial dan komitmen organisasi berpengaruh positif terhadap kinerja. Oleh karena itu, komitmen organisasi menjadi isu penting dalam konstelasi perubahan organisasi yang di dalamnya terkait dengan manajemen dan perilaku sumber daya manusia atau pegawai. Pada komitmen organisasi terkait dengan rasa identifikasi (kepercayaan terhadap nilai-nilai organisasi), keterlibatan (kesediaan untuk berusaha sebaik mungkin demi kepentingan organisasi) dan kompetensi (keinginan untuk tetap menjadi anggota organisasi yang bersangkutan). Tiga unsur utama dalam komitmen organisasi (rasa identifikasi, keterlibatan dan kompetensi) tersebut menjadi dasar yang sangat penting bagi pegawai untuk mencapai keberhasilan dalam melaksanakan tugasnya, sehingga tercipta kinerja yang baik. Dengan demikian pegawai yang mempunyai komitmen yang tinggi terhadap organisasi, maka akan meningkatkan kinerja pegawai tersebut.

Faktor lain yang dapat meningkatkan kinerja pegawai Dinas Sosial Daerah Kabupaten Tapanuli Selatan yaitu disiplin. Menurut Rivai (2009:96) disiplin diartikan 
sebagai suatu keadaan tertib dimana orangorang tergabung dalam suatu organisasi dan patuh terhadap peraturan yang telah ditetapkan dengan senang hati. Sedangkan menurut Hasibuan (2008:193), menyatakan bahwa disiplin adalah kesadaran dan ketaatan seseorang terhadap peraturan organisasi/instansi dan norma sosial yang berlaku. Dari beberapa pendapat itu dapat disimpulkan bahwa disiplin kerja adalah sikap ketaatan dan kesetiaan pegawai terhadap peraturan tertulis/tidak tertulis yang tercermin dalam bentuk tingkah laku dan perbuatan pada suatu organisasi untuk mencapai tujuan tertentu. Tujuan disiplin baik kolektif maupun perorangan yang sebenarnya adalah untuk mengarahkan tingkah laku pada realita yang harmonis.

Faktor lain yang dapat mempengaruhi kinerja pegawai Dinas Sosial Daerah Kabupaten Tapanuli Selatan adalah kemampuan kerja atau kemampuan diri pegawai. Menurut Robbins (2007:114) kemampuan diri adalah kapasitas individu untuk melakukan beragam tugas dalam suatu pekerjaan. Umumnya kapasitas individu dipengaruhi oleh kontribusi pengetahuan (knowledge), ketrampilan (skills), dan sikap (attitude) yang tertanam didalam pikiran yang berasal dari dalam diri sendiri, orang tua, pegawai dan lingkungan organisasi. Pada dasarnya kinerja dari seseorang merupakan hal yang bersifat individu, karena masing-masing individu memiliki tingkat kemampuan yang berbeda. Cascio (2006:221) mengemukakan bahwa kemampuan mental, intelegensi emosi, dan tacit knowledge dapat membantu membedakan pegawai yang berkinerja tinggi dengan pegawai yang berkinerja rendah.

Fenomena yang terjadi pada Dinas Sosial Daerah Kabupaten Tapanuli Selatan bahwa dalam mendukung kinerja, pegawai belum dapat menunjukkan kondisi yang optimal. Faktanya antara lain masih adanya keluhan para pegawai dalam menjalankan pekerjaannya masih terjadi dan penguasaan informasi teknologi masih perlu peningkatan. Gejala seperti ini jelas akan mengganggu kinerja pegawai sehingga perlu dilakukan pembenahan untuk meningkatkan kinerja Dinas Sosial Daerah Kabupaten Tapanuli Selatan. Selain dari pada itu tingkat kehadiran pegawai juga belum sepenuhnya menunjukkan kinerja yang baik karena masih ada pegawai yang datang terlambat, pulang sebelum jam kantor serta tidak berada di meja kerja pada waktu jam kerja.

\subsection{Batasan Masalah}

Berdasarkan uraian di atas, banyak faktor yang berpengaruh pada variabel kinerja pegawai Dinas Sosial Daerah Kabupaten Tapanuli Selatan, sehingga dalam penelitian ini peneliti membatasi kepada variabel independen yaitu disiplin kerja, komitmen organisasi, kemampuan kerja dan kinerja pegawai.

\subsection{Hioptesis}

Berdasarkan uraian teoritis dan kerangka konseptual di atas, maka dapat ditarik hipotesis penelitian ini sebagai berikut :

1) Disiplin kerja berpengaruh positif dan signifikan terhadap kinerja pegawai Dinas Sosial Daerah Kabupaten Tapanuli Selatan.

2) Komitmen organisasi berpengaruh positif dan signifikan terhadap kinerja pegawai Dinas Sosial Daerah Kabupaten Tapanuli Selatan.

3) Kemampuan diri berpengaruh positif dan signifikan terhadap kinerja pegawai Dinas Sosial Daerah Kabupaten Tapanuli Selatan.

4) Disiplin kerja, komitmen organisasi dan kemampuan diri berpengaruh positif dan signifikan terhadap kinerja pegawai Dinas Sosial Daerah Kabupaten Tapanuli Selatan.

\subsection{Tujuan Penelitian}

Tujuan dari penelitian ini adalah :

1) Untuk mengetahui dan menganalisis pengaruh disiplin kerja terhadap kinerja pegawai Dinas Sosial Daerah Kabupaten Tapanuli Selatan.

2) Untuk mengetahui dan menganalisis pengaruh komitmen organisasi terhadap kinerja pegawai Dinas Sosial Daerah Kabupaten Tapanuli Selatan.

3) Untuk mengetahui dan menganalisis pengaruh kemampuan kerja terhadap kinerja pegawai Dinas Sosial Daerah Kabupaten Tapanuli Selatan.

4) Untuk mengetahui dan menganalisis pengaruh disiplin kerja, komitmen organisasi dan kemampuan kerja terhadap kinerja pegawai Dinas Sosial Daerah Kabupaten Tapanuli Selatan.

\section{Metode Penelitian}

\subsection{Populasi}

Populasi adalah wilayah generasi yang terdiri dari atas objek/subjek yang mempunyai 
kualitas karakteristik tertentu yang disajikan oleh peneliti untuk dipelajari dan kemudian ditarik kesimpulannya. Berdasarkan defenisi tersebut, maka populasi dalam penelitian ini adalah para pegawai Dinas Sosial Daerah Kabupaten Tapanuli Selatan yang berjumlah 32 orang. Populasi ini tidak termasuk kepala dinas dan peneliti.

Tabel 1. Distribusi populasi berdasarkan bagian

\begin{tabular}{|c|l|c|}
\hline No & \multicolumn{1}{|c|}{ Keterangan } & $\begin{array}{c}\text { Jumlah } \\
\text { (Orang) }\end{array}$ \\
\hline 1 & Sekretariat & 7 \\
\hline 2 & $\begin{array}{l}\text { Bidang Perlindungan dan } \\
\text { Jaminan Sosial }\end{array}$ & 7 \\
\hline 3 & Bidang Rehabilitasi Sosial & 6 \\
\hline 4 & Bidang Pemberdayaan Sosial & 6 \\
\hline 5 & $\begin{array}{l}\text { Bidang Penanganan Fakir } \\
\text { Miskin }\end{array}$ & 6 \\
\hline \multicolumn{2}{|c|}{ Total } & 32 \\
\hline
\end{tabular}

\subsection{Sampel}

Sampel adalah elemen-elemen populasi yang dipilih atas dasar kemampuan mewakilinya. Untuk menjadi pedoman jika subjeknya atau populasinya kurang dari 100, maka lebih baik diambil semua sebagai sampel, sehingga penelitiannya merupakan penelitian populasi. Selanjutnya jika jumlah subjeknya atau populasinya besar atau lebih dari 100, maka dapat diambil persentasenya. Dengan teknik penarikan sampel secara total sampling, maka sampel dalam penelitian ini seluruh populasi yaitu 32 orang pegawai Dinas Sosial Daerah Kabupaten Tapanuli Selatan.

\subsection{Uji Normalitas}

Uji normalitas bertujuan untuk menguji apakah dalam model regresi variabel pengganggu (residual) memiliki distribusi normal. Seperti diketahui bahwa uji " $\mathrm{t}$ " dan uji $\mathrm{F}$ mengasumsikan bahwa nilai residual mengikuti distribusi normal.

Dalam penelitian ini pengujian normalitas dideteksi melalui analisa grafik P-P Plot.yang dihasilkan melalui SPSS. Adapun output grafik P-P Plot seperti terlihat pada gambar dibawah ini:

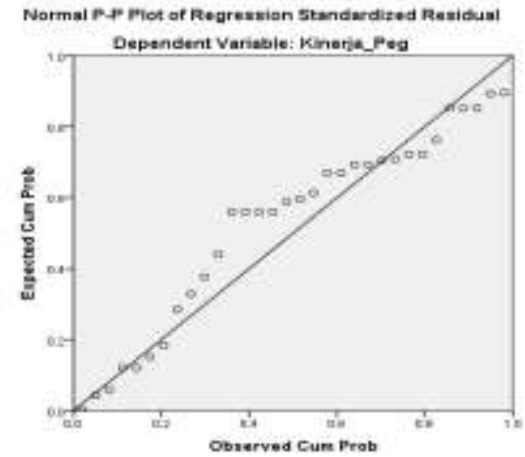

Gambar 1. Uji normalitas P-P Plot Test

Berdasarkan gambar 1 di atas, terlihat bahwa distribusi dari titik-titik data Disiplin kerja, Komitmen Organisasi, Kemampuan kerja dan kinerja menyebar. Grafik P-P Plot diatas menunjukan bahwa sebaran data menyebar disekitar garis diagonal, sehingga asumsi normalitas dipenuhi. Maka model regresi layak dipakai untuk memprediksi kinerja berdasarkan variabel independennya.

Berdasarkan gambar 2 dibawah terlihat bahwa grafik histogram memberikan pola distribusi normal tidak berpola distribusi melenceng (skwewness) ke kiri atau ke kanan, maka model regresi memenuhi asumsi normalitas.

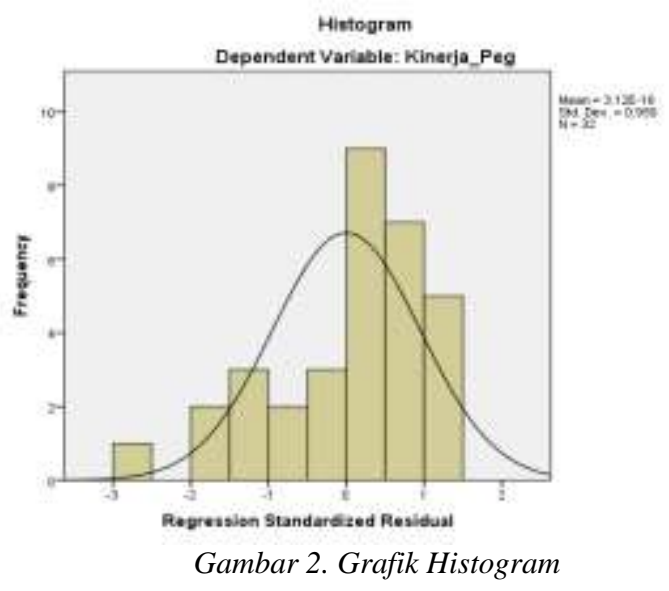

\subsection{Uji Multikolinearitas}

Metode untuk menguji ada tidaknya multikolinearitas dapat dilihat Tolerance Value dan Inflation Factor (VIF). Batas tolerance value adalah 0,10 atau nilai VIF adalah 10. Jika tolerance value $>0,10$ dan $\mathrm{VIF}<10$ maka tidak terjadi multikolinearitas dan sebaliknya jika tolerance value < 0,10 dan VIF > 10 maka terjadi multikoleniaritas. Hasil pengolahan dapat dilihat pada tabel 5.14 berikut ini: 
Tabel 2. Uji Multikolinearitas Coefficients $^{\mathrm{a}}$

\begin{tabular}{|c|c|c|}
\hline \multirow[t]{2}{*}{ Model } & \multicolumn{2}{|c|}{$\begin{array}{c}\text { Collinearity } \\
\text { Statistics }\end{array}$} \\
\hline & Tolerance & VIF \\
\hline (Constant) & & \\
\hline Disiplin_Kerja & .860 & 1.163 \\
\hline 'Komitmen_Org & .994 & 1.007 \\
\hline Kemampuan_Kerja & .860 & 1.163 \\
\hline
\end{tabular}

a. Dependent Variable: Kinerja_Peg

Sumber: Hasil Pengolahan SPSS Tahun 2020

Berdasarkan output tabel 5.14 diatas, hasil perhitungan nilai tolerance menunjukan tidak ada variabel independen yang memiliki nilai tolerance kurang dari 0,10 yang berarti tidak ada korelasi antara variabel independen yang nilainya lebih dari $95 \%$. Hasil perhitungan nilai variance inflaction factor (VIF) juga menunjukan hal yang sama, yaitu tidak ada satu variabel independen yang memiliki nilai VIF lebih dari 10. Jadi dapat disimpulkan bahwa tidak ada multikolinieritas antar variabel independen dalam model regresi.

\subsection{Uji Heteroskedastisitas}

Uji heteroskedastisitas dilakukan untuk mengetahui apakah dalam sebuah model regresi terjadi ketidaksamaan varians dari residual suatu pengamatan ke pengamatan lain. Jika varians dari residual dari suatu pengamatan ke pengamatan lain tetap disebut heteroskedastisitas.

Menganalisis data dalam pengujian asumsi klasik ini, peneliti menggunakan Program Statistical Product and Service Solution (SPSS) for Windows dapat dilihat pada gambar 5.3 berikut ini:

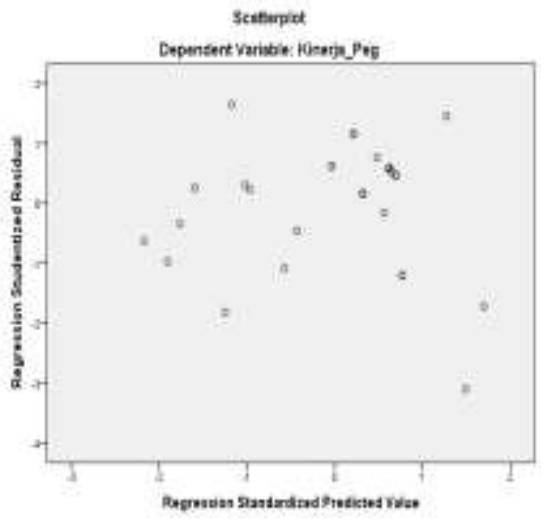

Gambar 2. Grafik scatterplot Uji Heteroskedastisitas

Dari gambar di atas menunjukkan bahwa diagram pencar tidak membentuk suatu pola atau acak, dengan demikian dapat dikatakan bahwa regresi tidak mengalami gangguan heteroskedastisitas pada model regresi sehingga model regresi layak dipakai untuk mengetahui kinerja pegawai (Y) berdasarkan variabel bebasnya.

\subsection{Uji Autokorelasi}

Uji autokorelasi digunakan untuk melihat hubungan antara variabel bebas memiliki hubungan sama kuat atau tidak, dimana untuk melihat hubungan atau tidak hubungan secara autokorelasi dapat dilihat dengan Uji DurbinWatson (DW test)

Uji Durbin-Watson hanya digunakan untuk autokorelasi tingkat satu (first order autocorrelation) dan mensyaratkan adanya intercept (kostanta) dalam model regresi dan tidak ada variabel lain diantara variabel independent.

Tabel 3. Uji Durbin-Watson (DW test)

Model Summary $^{b}$

\begin{tabular}{l|l|r|r|r|}
\hline \multirow{2}{*}{ Model } & \multicolumn{3}{|c|}{ Change Statistics } & \multirow{2}{*}{ Durbin-Watson } \\
\cline { 2 - 4 } & $\mathrm{df} 1$ & $\mathrm{df} 2$ & Sig. F Change & \\
\hline 1 & $3^{\mathrm{a}}$ & 28 & .000 & 1.866 \\
\hline a. Predictors: (Constant), Kemampuan_Kerja, Komitmen_Org, Disiplin_Kerja \\
b. Dependent Variable: Kinerja_Peg \\
Sumber: Hasil Pengolahan SPSS Tahun 2020
\end{tabular}

Berdasarkan tabel 3 diatas diperoleh nilai Durbin-Watson sebesar 1.866. Nilai DurbinWatson menurut tabel dengan $n=32$ responden dan $\mathrm{K}=3$ (dalam hal ini adalah jumlah variabel bebas) didapat angka $\mathrm{dl}=1.2437 \mathrm{dan} \mathrm{du}=$
1.6505. oleh karena itu nilai DW hitung $>d u$ $(1.866>1.6505)$, maka dapat disimpulkan bahwa tidak terdapat autokorelasi dalam model regresi maka model layak untuk digunakan. 


\section{Evaluasi dan Pembahasan}

\subsection{Hasil Analisis Regresi Linear Berganda}

Analisis regresi linier berganda digunakan untuk mengetahui besar pengaruh Disiplin kerja, Komitmen Organisasi dan Kemampuan kerja terhadap kinerja pegawai di Kantor Dinas Sosial Daerah Kabupaten Tapanuli Selatan. Analisis dilakukan dengan menggunakan bantuan SPSS dengan output sebagai berikut:

Tabel 4. Regresi Linear Berganda

Coefficients $^{\mathrm{a}}$

\begin{tabular}{|rl|r|r|r|r|r|}
\hline \multirow{2}{*}{ Model } & \multicolumn{2}{|c|}{$\begin{array}{c}\text { Unstandardized } \\
\text { Coefficients }\end{array}$} & $\begin{array}{l}\text { Standardized } \\
\text { Coefficients }\end{array}$ & \multirow{2}{*}{ Sig. } & \\
\cline { 2 - 5 } & \multicolumn{1}{|c|}{ B } & Std. Error & \multicolumn{1}{c|}{ Beta } & & \\
\hline \multirow{2}{*}{1} & (Constant) & 7.327 & 3.232 & & 2.267 & .031 \\
& Disiplin_Kerja & .403 & .101 & .494 & 3.990 & .000 \\
& Komitmen_Org & .218 & .080 & .313 & 2.717 & .011 \\
& Kemampuan_Kerja & .316 & .101 & .388 & 3.135 & .004 \\
\hline
\end{tabular}

Sumber: Hasil Pengolahan SPSS Tahun 2020

Berdasarkan pengolahan data yang terlihat pada tabel output kolom kedua bagian B (Unstandardized Coefficients), diperoleh persamaan regresi linier berganda yaitu:

$$
y=a+b_{1} x_{1}+b_{2} x_{2}+b_{3} x_{3}+\varepsilon
$$

$$
Y=7.327+0.403 X_{1}+0.218 X_{2}+0.316 X_{3}+\varepsilon
$$

Dengan persamaan regresi linier

berganda tersebut dapat dijelaskan bahwa:

1) Nilai konstanta adalah sebesar 7.327 hal ini menyatakan bahwa jika variable Disiplin kerja dan Komitmen Organisasi serta Kemampuan kerja diabaikan, maka nilai kinerja pegawai sebesar 7.327.

2) Koefisien regresi untuk variabel Disiplin kerja sebesar 0.403 hal ini menunjukkan bahwa setiap kenaikan $1 \%$ faktor Disiplin kerja maka akan meningkatkan kinerja pegawai sebesar $40.3 \%$.
3) Koefisien regresi untuk variabel Komitmen Organisasi sebesar 0.218 hal ini menunjukkan bahwa setiap kenaikan $1 \%$ faktor Komitmen Organisasi maka akan meningkatkan kinerja pegawai sebesar $21.8 \%$

4) Koefisien regresi untuk variable Kemampuan kerja sebesar 0.316 hal ini menunjukkan bahwa setiap kenaikan $1 \%$ faktor Kemampuan kerja maka akan meningkatkan kinerja pegawai sebesar $31.6 \%$

\subsection{Uji Serempak}

Untuk mengetahui pengaruh Disiplin kerja, Komitmen Organisasi dan Kemampuan kerja sebagai variabel bebas (X) terhadap kinerja pegawai sebagai variabel terikat $(\mathrm{Y})$ di Kantor Dinas Sosial Daerah Kabupaten Tapanuli Selatan dapat dilihat pada tabel 5.17 berikut.

Tabel 5. Hasil Uji Serempak

\begin{tabular}{|c|c|c|c|c|c|c|}
\hline \multicolumn{2}{|c|}{ Model } & $\begin{array}{l}\text { Sum of } \\
\text { Squares }\end{array}$ & $\mathrm{df}$ & Mean Square & $\mathrm{F}$ & Sig. \\
\hline \multirow{3}{*}{1} & Regression & 82.266 & 3 & 27.422 & 15.929 & $.000^{\mathrm{b}}$ \\
\hline & Residual & 48.203 & 28 & 1.722 & & \\
\hline & Total & 130.469 & 31 & & & \\
\hline
\end{tabular}

ANOVA $^{\mathrm{a}}$

b. Predictors: (Constant), Kemampuan_Kerja, Komitmen_Org, Disiplin_Kerja

Dari tabel 5 diatas, diperoleh nilai $\mathrm{F}_{\text {hitung }}$ sebesar 15.929. Dengan menggunakan confidence interval (CI) $95 \%$ df 3:32 ( $\alpha=$ 0.05 ) maka dari tabel distribusi $F$ diperoleh nilai 2.90. Dengan demikian $F_{\text {hitung }} 15.929>F_{\text {tabel }}$
2.90, maka $\mathrm{H}_{0}$ ditolak dan $\mathrm{H}_{1}$ diterima, artinya variabel Disiplin kerja, Komitmen Organisasi serta Kemampuan kerja sebagai variabel bebas (X) berpengaruh signifikan terhadap variabel 
kinerja pegawai di Kantor Dinas Sosial Daerah Kabupaten Tapanuli Selatan.

Pada tabel 5 di atas terlihat nilai signifikansi sebesar $0.000^{\mathrm{b}}$ lebih kecil dari $\alpha=$ 0,05 , hal ini berarti bahwa variabel Disiplin kerja, Komitmen Organisasi serta Kemampuan kerja sebagai variabel bebas memiliki pengaruh yang highly significant. Secara serempak variabel Disiplin kerja, Komitmen Organisasi serta Kemampuan kerja menunjukkan pengaruh sangat nyata terhadap kinerja pegawai di Kantor
Dinas Sosial Daerah Kabupaten Tapanuli Selatan.

\subsection{Uji Parsial}

Uji pengaruh variabel Disiplin kerja, Komitmen Organisasi pegawai serta Kemampuan kerja secara parsial dapat dilihat pada tabel 5.19 berikut:

Dari tabel 6 dibawah diperoleh nilai $t_{\text {hitung }}$ masing-masing variabel. Nilai $t_{\text {hitung }}$ tersebut selanjutnya dibandingkan dengan nilai $t_{\text {tabel }}$ pada tingkat kepercayaan $95 \%$ atau $\alpha=0,05$. Nilai $t_{\text {tabel }}$ pada df 3:32 dengan $\alpha=0,05$ adalah 2.037.

Tabel 6. Hasil Uji Parsial

Coefficients $^{\mathrm{a}}$

\begin{tabular}{|c|c|c|c|c|c|c|}
\hline \multirow{2}{*}{\multicolumn{2}{|c|}{ Model }} & \multicolumn{2}{|c|}{$\begin{array}{c}\text { Unstandardized } \\
\text { Coefficients }\end{array}$} & $\begin{array}{l}\text { Standardized } \\
\text { Coefficients }\end{array}$ & \multirow[t]{2}{*}{$\mathrm{t}$} & \multirow[t]{2}{*}{ Sig. } \\
\hline & & B & Std. Error & Beta & & \\
\hline \multirow{4}{*}{1} & (Constant) & 7.327 & 3.232 & & 2.267 & .031 \\
\hline & Disiplin_Kerja & .403 & .101 & .494 & 3.990 & .000 \\
\hline & Komitmen_Org & .218 & .080 & .313 & 2.717 & .011 \\
\hline & Kemampuan_Kerja & .316 & .101 & 388 & 3.135 & .004 \\
\hline
\end{tabular}

Sumber: Hasil Pengolahan SPSS Tahun 2020

Pengaruh parsial dari variabel Disiplin kerja $\left(\mathrm{X}_{1}\right)$ diperoleh dengan nilai $\mathrm{t}_{\text {hitung }}$ sebesar 3.990 , dengan demikian $t_{\text {hitung }}>t_{\text {tabel }}(3.990>$ 2.037) dan nilai signifikan sebesar $0.000<0.05$, maka $\mathrm{H}_{0}$ diterima dan $\mathrm{H}_{1}$ ditolak, yang berarti bahwa variabel Disiplin kerja $\left(\mathrm{X}_{1}\right)$ berpengaruh positif terhadap kinerja pegawai di Kantor Dinas Sosial Daerah Kabupaten Tapanuli Selatan. Hal ini berarti bahwa apabila Disiplin kerja $\left(\mathrm{X}_{1}\right)$ meningkat, maka kinerja pegawai Kantor Dinas Sosial Daerah Kabupaten Tapanuli Selatan juga akan meningkat.

Pengaruh parsial dari variabel Komitmen Organisasi $\left(\mathrm{X}_{2}\right)$ diperoleh dengan nilai $\mathrm{t}_{\text {hitung }}$ sebesar 2.717, dengan demikian $t_{\text {hitung }}>t_{\text {tabel }}$ $(2.717>2.037)$ dan nilai signifikan sebesar $0.011<0.05$, maka $\mathrm{H}_{0}$ ditolak dan $\mathrm{H}_{1}$ diterima, yang berarti bahwa variabel Komitmen Organisasi $\left(\mathrm{X}_{2}\right)$ berpengaruh positif dan signifikan terhadap kinerja pegawai Kantor Dinas Sosial Daerah Kabupaten Tapanuli Selatan. Hal ini berarti bahwa apabila Komitmen Organisasi $\left(\mathrm{X}_{2}\right)$ meningkat maka kinerja pegawai Kantor Dinas Sosial Daerah
Kabupaten Tapanuli Selatan juga akan meningkat.

Pengaruh parsial dari variabel Kemampuan kerja $\left(\mathrm{X}_{3}\right)$ diperoleh dengan nilai $t_{\text {hitung }}$ sebesar 3.135 , dengan demikian $t_{\text {hitung }}>t_{\text {tabel }}(3.135>$ 2.037) dan nilai signifikan sebesar $0.004<0.05$, maka $\mathrm{H}_{0}$ ditolak dan $\mathrm{H}_{1}$ diterima, yang berarti bahwa variabel Kemampuan kerja $\left(\mathrm{X}_{3}\right)$ berpengaruh positif dan signifikan terhadap kinerja pegawai Kantor Dinas Sosial Daerah Kabupaten Tapanuli Selatan. Hal ini berarti bahwa apabila Kemampuan kerja $\left(\mathrm{X}_{3}\right)$ meningkat maka kinerja pegawai Kantor Dinas Sosial Daerah Kabupaten Tapanuli Selatan juga akan meningkat.

\subsection{Uji Determinasi}

Selanjutnya berdasarkan nilai koefisien determinasi $\left(\mathrm{R}^{2}\right)$ diketahui besarnya pengaruh perubahan variabel Disiplin kerja, Komitmen Organisasi serta Kemampuan kerja terhadap kinerja pegawai di Kantor Dinas Sosial Daerah Kabupaten Tapanuli Selatan sebagai berikut: 
Tabel 7. Koefisien Determinasi

Model Summary ${ }^{\mathbf{b}}$

\begin{tabular}{|c|c|c|c|c|c|c|}
\hline \multirow[t]{2}{*}{ Model } & \multirow[t]{2}{*}{$\mathrm{R}$} & \multirow[t]{2}{*}{ R Square } & \multirow{2}{*}{$\begin{array}{c}\text { Adjusted R } \\
\text { Square }\end{array}$} & \multirow{2}{*}{$\begin{array}{l}\text { Std. Error of } \\
\text { the Estimate }\end{array}$} & \multicolumn{2}{|c|}{ Change Statistics } \\
\hline & & & & & $\begin{array}{l}\text { R Square } \\
\text { Change }\end{array}$ & F Change \\
\hline 1 & $.794^{\mathrm{a}}$ & .631 & .591 & 1.312 & .631 & 15.929 \\
\hline
\end{tabular}

Sumber: Hasil Pengolahan SPSS Tahun 2020

Berdasarkan tabel 7 diatas diperoleh angka Adjusted R Square sebesar 0.591 atau (59.1\%). Hal ini menunjukkan bahwa persentase sumbangan pengaruh variabel independen (Disiplin kerja, Komitmen Organisasi dan Kemampuan kerja) terhadap variabel dependen (kinerja pegawai) sebesar 59.1\%. Atau variasi variabel independen yang digunakan dalam model (Disiplin kerja, Komitmen Organisasi dan Kemampuan kerja) mampu menjelaskan sebesar $59.1 \%$ variasi variabel dependen (kinerja pegawai). Sedangkan sisanya sebesar 40.9\% dipengaruhi atau dijelaskan oleh variabel lain yang tidak dimasukkan dalam model penelitian ini.

Berdasarkan hasil analisis diketahui bahwa nilai koefisien regresi yang paling tinggi adalah variabel Disiplin kerja $\left(\mathrm{X}_{1}\right)$ sebesar 0.494 atau 49.4\%. Hal ini berarti bahwa Disiplin kerja $\left(X_{1}\right)$ pegawai berpengaruh lebih dominan terhadap kinerja pegawai Kantor Dinas Sosial Daerah Kabupaten Tapanuli Selatan.

\section{Kesimpulan}

Dari hasil analisis yang telah dibahas, maka ditarik kesimpulan sebagai berikut:

1) Disiplin kerja, komitmen organisasi serta kemampuan kerja berpengaruh signifikan terhadap kinerja pegawai di Kantor Dinas Sosial Daerah Kabupaten Tapanuli Selatan dengan nilai $\mathrm{F}_{\text {hitung }} 15.929>\mathrm{F}_{\text {tabel }} 2.90$ dan nilai signifikansi sebesar $0.000^{\mathrm{b}}$

2) Disiplin kerja berpengaruh signifikan terhadap kinerja pegawai di Kantor Dinas Sosial Daerah Kabupaten Tapanuli Selatan dengan nilai $\mathrm{t}_{\text {hitung }}>\mathrm{t}_{\text {tabel }}(3.990>2.037)$ dan nilai signifikansi sebesar 0.000

3) Komitmen organisasi berpengaruh signifikan terhadap kinerja pegawai di Kantor Dinas Sosial Daerah Kabupaten Tapanuli Selatan dengan nilai $t_{\text {hitung }}>t_{\text {tabel }}$ $(2.717>2.037)$ dan nilai signifikansi sebesar 0.011

4) Kemampuan kerja berpengaruh signifikan terhadap kinerja pegawai di Kantor Dinas Sosial Daerah Kabupaten Tapanuli Selatan dengan nilai $\mathrm{t}_{\text {hitung }}>\mathrm{t}_{\text {tabel }}(3.135>2.037)$ dan nilai signifikansi sebesar 0.004

5) Angka Adjusted $R$ Square sebesar 0.591 atau $(59.1 \%)$ menunjukkan bahwa persentase sumbangan pengaruh variabel independen (disiplin kerja, komitmen organisasi serta kemampuan kerja) terhadap variabel dependen (kinerja pegawai) sebesar 59.1\%.

\section{DAFTAR PUSTAKA}

Abdullah, Z., Darwanis., dan Zein, B. (2013). Pengaruh sikap kerja terhadap kinerja auditor melalui motivasi kerja sebagai variabel intervening. Jurnal Akuntansi, Volume 2, No. 1, November 2012

Barnardin (2008), Mengelola Sumber Daya Manusia, PT. Gramedia, Jakarta

Cascio (2006), Organisasi. Edisi Kedelapan, Jilid 2. Binarupa Aksara . Jakarta

Colquitt, LePine, Wesson, 2009, Organizational Behavior Improving Performance and Commitment in The Workplace, Mc Graw Hill International Edition

Cross, T.M dan Lynch. R.R. (2012). Peniliaian dan Evaluasi Kinerja: Konsep dan Praktik. Jakarta. Penerbit Ghalia Indonesia

Dessler, Gary. (2007). Manajemen Sumber Daya Manusia (Jilid I). Jakarta : Indeks

Gibson, James L., Ivancevich, John M., Donnely, James H., and Konopaske (2009) Organizations: Behavior, Structure, Processes,New York, McGraw Hill.

Gorda, IGN. 2004. Manajemen Sumber Daya Manusia. Edisi Revisi. Cetakan Kedua. Denpasar: Astabrata

Handoko T, Hani (2008), Manajemen Personalia dan Sumber Daya Manusia, Edisi Kedua, BPFE Yogyakarta

Hasibuan, Malayu S. P. (2008). Manajemen Sumber Daya Manusia. Edisi Revisi Jakarta: PT. Bumi Aksara

Husnan (2004), Manajemen Personalia dan Sumber Daya Manusia, Edisi Kedua, BPFE Yogyakarta 
Ivancevich, G., and Koropaske, D., (2010) Organizations: Behavior, Stucture, Process, Singapore, McGraw Hill Company

Ivancevich, John M., Konopaske, Robert., and Matteson, Michael T., (2007) Organizational Behavior and Management, $7^{\text {th }}$ edition, McGraw Hill, Alih Bahasa Gina Gania, Perilaku dan Manajemen Organisasi, Jilid 1, Edisi 7, Jakarta, Erlangga

Liao (2012), The impact of work values, work attitudes on job performance of Green Energy Industry Employee in Taiwan

Mangkunegara, Anwar, Prabu. (2009). Evaluasi Kinerja SDM, Cetakan 4, Bandung : Refika Aditama

Martoyo, Susili (2004), Manajemen Sumber Daya Manusia, Edisi Ketiga, Cetakan Keempat, Ghalia Jakarta

Mathis, Robert L and Jackson, John H, 2006, Manajemen Sumber Daya Manusia, Edisi 10, terjemahan, Salemba Empat

Milkovich, T George and Newman, Jerry M, 2008,Competency, Mc Graw Hill International Edition

Moekijat (2008), Latihan dan Pengembangan Sumber Daya Manusia, Cetakan ke Empat, Maju Mundur, Bandung

Murphy, Kevin R and Cleveland, Jeanette N, 2012, Performance Appraisal : An Organizational Perspective,Colorado State University

Nitisemito S Alex (2008), Manajemen Personalia, Cetakan Keempat, Ghalia, Jakarta

Petty, Ricard E., Brinol, Pablo., dan Tormala, Zakary L., (2012) "Thought Confidence as a Determinant of Persuasion: The Self ValidationHypothesis", Journal of Personality and Social Psychology, pp. 722734

Riduwan. (2007). Skala Pengukuran VariabelVariabel Bandung : Alfabeta

Rivai, Veithzal dan Sagala, Ella Jauvani. (2009). Manajemen Sumber Daya Manusia Untuk Perusahaan : Dari Teori ke Praktek. Jakarta : PT. Rajagrafindo Persada

Robbins, Stephen P., dan Judge, Timothy A., (2008) Perilaku Organisasi, Terjemahan Edisi Dua Belas, Jakarta, Salemba Empat.

(2009) Organizational Behavior, 13 ${ }^{\text {th }}$ edition, New Jersey, Pearson Education, Upper Saddle River

Sedarmayanti. (2004). Good Governance (Kepemerintahan Yang Baik), Bandung : Mandar Maju
Siagian, Sondang. (2008). Manajemen Sumber Daya Manusia (cetakan 15). Jakarta: Bumi Aksara

Sink, R dan Tuttle, J.K. (2009). Evaluasi Kinerja. Jakarta: Indeks Kelompok Gramedia

Sri Yani 2005, Hubungan Antara Kompetensi Manaajerial dan Komitmen Organisasi Dengan Kinerja Pejabat Struktural Eselon III-IV Pada Sekretariat Jenderal Dewan Perwakilan Rakyat Republik Indonesia, Tesis, Universitas Indonesia, Jakarta

Sugiyono. 2010. Metode Penelitian Bisnis. Alfabeta Bandung

Terry George \& Rue, Leslie W alih bahasa Terry (2008), Dasar-Dasar Manajemen, Cetakan Ketujuh Bumi Aksara Jakarta

Torang Sitanggang 2005, Pengaruh Persepsi Mengenai Komitmen dan Budaya Organisasi Terhadap Persepsi Mengenai Kinerja Pegawai Pajak Di Direktorat Pemerikasaan, Penyidikan dan Penagihan Pajak Direktorat Jenderal Pajak, Tesis, Universitas Indonesia

Triton PB (2005), Paradigma Baru Manajemen Sumber Daya Manusia, Tugu Yogyakarta. (2006), SPSS 12.00 Terapan Riset Statistik Parametrik, Andi Yogyakarta.

Ulida L. Toruan 2004, Hubungan Antara Kompetensi dan Motivasi Terhadap Kinerja Pejabat Struktural di Badan Kepegawaian Negara, Tesis, Universitas Indonesia, Jakarta Zauhar. (2008). Motivasi dan Pemotivasian dalam Manajemen. Raja Grafindo Persada, Jakarta

Zin, R. M., (2004) "Perception of Professional Engineers Toward Quality of Work Life and Organizational Commitment a Case Study", Gadjah Mada InternationalJournal of Business, 6(3), 323-334. 